the National Society for Clean Air is trying to forestal such cynicism. The annual conference of the society is being held in Blackpool this week, and papers on various aspects of air pollution are being presented. The work of the society was described by Sir John Charrington in his presidential address on Tuesday. Sir John described the change of emphasis from industrial smoke to vehicle pollution and called for amendments to the Clean Air Act.

Air pollution from road vehicles was the subject of the report of the technical committee which was presented by Dr Albert Parker. Carbon monoxide is the principal pollutant in exhausts, although nitrogen oxides and smoke also occur. In Britain less than one-third of atmospheric carbon monoxide comes at present from vehicles, but if present rates of increase continue the amount discharged will have doubled by 1980 to more than 10 million tons a year. The danger from carbon monoxide arises particularly in traffic jams, when there is little chance of dispersion. Fifty p.p.m. is the maximum concentration of carbon monoxide allowed for an eight hour day in industry, and yet in Oxford Street recently 360 p.p.m. was measured. There is as yet no legislation in Britain for controlling emission from petrol engine vehicles, and the British Standard Specification for diesel engines is above the present emission level set by most. manufacturers. Work continues, however, on modifications to petrol engine design, for if it is ensured that all fuel is burnt, there will be little poisonous exhaust. Recirculation of crankcase fumes helps, and fuel injection systems and modified carburettors have been installed in some cars. The initial cost of the vehicle is increased, but fuel consumption is improved. It is hoped that preliminary murmurs from the Ministry of Transport on this subject will soon be transformed into effective schemes for checks and controls.

Industries using dangerous materials can keep checks on their employees, but waste substances that escape into the surrounding countryside can have serious effects. In a paper presented on Tuesday, beryllium, asbestos and fluorides were discussed. Illness and death can occur in both animals and humans living near processing plants, or from contact with industrial workers and their belongings, but no suggestions were made for improving the situation. The paper ended with a commendation of the care taken by those responsible for controls on radioactive waste.

By contrast, Dr E. F. Schumacher, economic adviser to the National Coal Board, considered the dangers of radioactive pollution. Too often these days decisions are based solely on economic considerations, with little reference to environmental factors. Pollution of the atmosphere by radioactive substances for the sake of cheaper electricity was the example Dr Schumacher used in his Des Voeux memorial lecture, when he related economics to clean air problems.

And so to the domestic scene, where keeping the home fires burning produces an estimated $£ 280$ million worth of damage every year. Working on an average figure of $£ 16$ for conversion to smokeless heating, the capital cost for cleaning up the black areas of England once and for all would come to $£ 100$ million. In giving these figures, $\mathrm{Mr}$ A. D. Smith described the situation as economically and technically crazy, because pollution from domestic smoke is the easiest type to remove. If a date could be set when Treasury grants for conversion would be stopped, people might jump to get their money while they can.

\section{Worthy Cause}

THIs month, Mr Peter Scott will launch an appeal for $£ 75,000$ for development at Wicken. Fen-the remnant of the once great fens of Cambridgeshire. Wicken Fen. reserve, one of the oldest and most famous nature reserves in Britain, is approximately 700 acres in extent and has long been the site of biological and nature studies. But in recent years there has been a great increase in the use of the area by members of the general public, school parties and groups of students. To encourage these activities while at the same time conserving vegetation and wild life, the Wicken Fen Local Committee of the National Trust has made two sensible proposals. One, following the American National Parks pattern, is the erection of an open air laboratory with associated museum, lecture room and display unit and the provision of picnic and other facilities for visitors. A resident warden naturalist, appointed by the committce, will be in charge of the laboratory, but there will not be a permanent staff. Taboratory facilities, including exhibits and maps, will be available to interested parties, and school children will be allowed to examine in the laboratory their specimens at the end of a day's collecting. The other proposal is to create a marshland reserve in which a new range of aquatic and marsh communities can become established and provide a valuable habitat and migration refuge for many species of birds.

There has already been considerable progress in the management and conservation of the reserve. A ten acre mere, opened in 1955, is now the haunt of thousands of birds. A sixty acre reed field has also been established on the fen and, in the past three years, more than a mile of dyke has been cleared out. More manpower and modern implements are needed, however, to clear choked ditches and the wilderness of bushes - the result of years of financial difficulties. The present income of the fen, entirely composed of voluntary subscriptions and donations, is quite inadequate to meet these urgent needs.

The cause is particularly worthy. Instead of trying to restrict use of the reserve, the committee wishes to encourage public interest, while at the same time safeguarding the area.

\section{Urban Grove for Academe \\ from Brenda Maddox}

Manchester is in the throes of a strenuous attempt to transform its academic community. The City Council, the University, the Institute of Science and Technology and the city's various colleges and hospitals are collaborating to create a green "educational precinct" in an area now engulfed by smog, traffic and slum. By 1984 the results of their efforts should be in place. There will be a strip, one and a quarter miles long and one-third of a mile wide, with the beautifully black university at its centre. Green grass and elevated pedestrian walkways will sweep from the site of the United Manchester Hospitals on the south to the group of city colleges on the north, and then east to take in 